\title{
Ornament on the Pendhok of the Surakarta Kris
}

\section{Guntur}

The Batik Department, the Faculty of Fine Art and Design, the Indonesian Institute of Arts Surakarta Jl. Ki Hadjar Dewantara 19 Surakarta, Central Java, Indonesia

gunturisi@yahoo.co.id

The type of ornament found on the Javanese kris pendhok is rarely discussed from an iconographic point of view. The pendhok is the decorative protection plating found on the sheath of the kris, usually made from metals such as silver, bronze, copper, brass, and even gold. The kris is a Javanese dagger. This essay focuses on the pendok ornament of the Surakarta kris, and on its symbolism. The pendhok is a 'patronage' art, traditionally manufactured by palace's mranggi-s(the sheath maker), and today by kris craftsmen. Its various motifs--vegetation, plants, animals, or other motifs--are combined with lung-lungan (curly, vegetation-looking forms) in such a way as to create symmetric-vertical ornaments. The lung-lungan and alas-alasan (the forest as cosmos) motifs are more numerous than flora, wayang puppets, and geometrical motifs. The designs emphasize symmetry, repetition and harmony as their basic principle. The ornament style is believed to embody the 'syncretic-mystique' of Javanese Islam. The ornaments embossed on the surface usually refer to pre-Islamic, Hindu-Buddha notions.

Keywords: ornament, pendhok, lung-lungan, alas-alasan, style, mranggi, Surakarta, Java

\section{Ornamen Pada Pendhok Dari Keris Surakarta}

Ornamen pendhok keris sebagai ikonografi Jawa jarang dibahas. Pendhok adalah lapisan dekoratif pelindung keris, yang biasanya terbuat dari berbagai logam seperti perak, perunggu, tembaga, kuningan, dan bahkan emas. Keris adalah jenis senjata tusuk Jawa. Artikel ini difokuskan pada hiasan pendhok dari keris Surakarta, dan simbolismenya dalam pencitraan Jawa. Pada awalnya, ornamen pendhok adalah seni 'patron', yang dibuat oleh mranggi istana (pembuat sarung), dan saat ini 'diciptakan kembali' oleh para pembuat keris di banyak tempat. Motif bunga, tanaman, hewan, atau figural pada pendhok, adalah komposisi dan penggabungan dengan lung-lungan (penggayaan tanaman) sebagai cara untuk membentuk irama ornamen secara simetris-vertikal, ornamen disederhanakan sebagai lung-lungan. Motif lung-lungan dan alas-alasan (kosmos hutan dalam imajinasi spiritual), mendominasi gaya ornamen dibandingkan dengan motif lain seperti tanaman/flora, wayang (boneka), dan geometri. Komposisi simetri, repetitif, dan harmoni menjadi yang paling 'prinsip' pada desain. Gaya ornamen diyakini melambangkan 'sinkretis-mistik' dari Jawa - Islam, ornamen yang 'timbul' pada permukaan yang berdimensi, menjadi ekspresi relief, yang sebagian besar menandakan seni yang diadopsi pra-Islam: Hindu - Buddha

Kata kunci: ornament, pendhok, lung-lungan, alas-alasan, gaya, mranggi, Surakarta, Jawa

Peer review : 9 - 23 Agust 2018, Accepted : 3 September 2018 


\section{INTRODUCTION}

The pendhok ornament, in particular that of the Surakarta kris, is not often a topic of study. The kris comprises: (1) the Pamor, the nickel pattern of the blade that is believed to possess a supernatural values; its aesthetic value rests on the forging process. According to Brown, the pamor is not an ornament; it has its own power (Brown \& Hutton 2011:112). (2) The Warangka (the sheath), its value depends on the quality of the wood used to make it; associated to the warangka is the pelet kendit, a dark brown, black, or white that appears on the sheath's surface (Harsrinuksmo 2004).

The pendhok ornament is not taken into accounts when it come to qualifying the style of a kris. Its incorporation on the pendhok is simply for beautification purpose. The pendhok does not have anything like pamor, or pelet kendhit, referring to Meyer's concept of style, which includes elements, qualities, and expression - in individual or collective art (Meyer, 287). The 'ukir-ukiran', or wood etching and carving in a tri-dimentional way, is considered as being the foundation of style.

The 'ukir-ukiran' found on the pendhok is not the subjects of style in kris made during the Islamic Mataram period, between 1584 (Panembahan Senapati) and 1788 (Paku Buwana III), also known as kris from the tangguh nom or young period. The kris made during the Kartasura sub-period are known as tangguh tengahan (middle period). Groneman argues that the ornaments found on pendhok are just like batik motifs. There are pendhok with special motifs such as semen jlengut, which may only be used by kings (Groneman, 1910:189). Similarly, following a regulation emitted by Paku Buwono IV, 1788 - 1820 (Margana, 2005:289,292) some motifs are banned on pendhok: The parijata (swollen rice), the tatahan sawat (sawat (throw) carved), and the kemalon abang (red kemalon, referring to the hue of the kemalo's tree). The gaps created by such regulations explains why the style of Surakarta kris is dominated by other sheath motifs, such as the ladrang and the gayaman, with a hilt of tunggak semi.

The making of kris became an important manufacture in the1800s. This was due to demographic reason, Surakarta being more populated than Yogyakarta, both being native-ruled province under the control of the Dutch East India Company (VOC), and the British East India Compa$n y$ in 1811-1815. The sheath was produced by specialists called tukang mranggi (Raffles 1817). Raffles noted that, compared to kris from other islands, Java kris were the most simple Raffles 2008:188). The Surakarta " kris should have the sheath of the sátrian (knight) fashion, and the handle should be that of tunggak semi (spring stump)" (Raffles, 1817:95). His description referred to the kris culture of the Surakarta Palace court. The ladrang and gayaman sheath, and the tunggak semi hilt (Yuwono 2012) are characteristic of the Surakarta kris. The Surakarta kris is believed to have

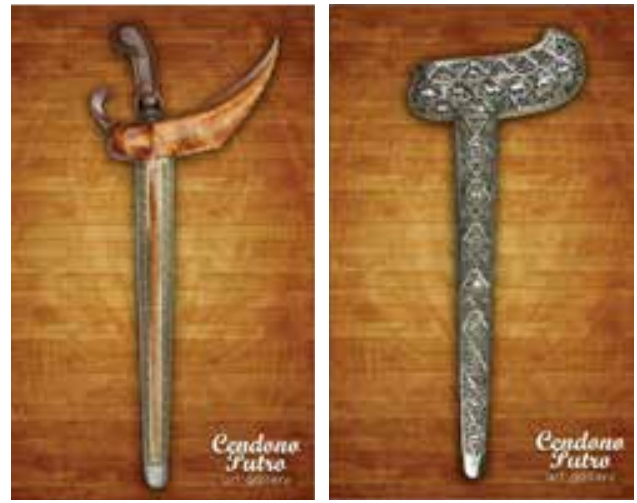

Figure 1. The sheath of Surakarta kris:

(a) Ladrang (b) Gayaman

be conceptualized by PB III in 1749 - 1788, to differentiate it from the tangguh tengahan kris of the Kasunanan Kartasura (1680 - 1745). After the Giyanti's agreement of 1755 , style had political connotations and, accordingly had to be different there from the style of the Kasultanan of Yogyakarta, the Western half of Mataram. The Giyanti agreement is an important document for understanding the history of Java (Ricklefs, 2014:11).

During Vorstenlanden (Princely Lands) era, the royal court sought to maintain authority over society by building up personal symbols for the nobility and public symbols to keep alive tradition (Kuntowijoyo, 2004:22-41). The nobility patronized the arts. The kris became an art manufactured by pandi (ironsmiths), whereas the sheaths/scabbards were produced by mranggi (Raffles, 1817:163-173). Surakarta's pendhok refers to the post-Kartasura period, and retained many differences with its Yogyakarta equivalent. Its style was reproduced by village mranggi (the sheath maker).

The legacy of the Surakarta's sheath form is found in the gayaman and ladrang (called branggah in Yogyakarta). The sheath of ladrang is commonly used at official ceremonies, as sign of respect toward tradition. There are four main types of ladrang, Kasatriyan, Kadipaten, Kacir, dan Capu, and each type has subtypes. The gayaman complements the dress during unofficial events. In its simplest form, it is used during at war, with its sheath functioning a shield, deflector, and to shovel (Wibawa, 2008:42).

The pendhok underlines the notions of ornamentation, beauty and harmony such as valued in the Javanese - Surakarta culture. The ornament usually applied on pendhok is the lung or lung-lungan. Paku Buwono XIII (2005-2011) used a kris in the gayaman style when on his throne, and the ornament on its pendhok was a rythmic vegetal motif sweet potato plants, believed to embody the notion of sustainable living (Hidayat, 2012:105). The following carved ornament are: cukitan, wudulan, and sunggingan (the layered/gradation of colors) which are refined and wavy. The first-four techniques use metal such as brass, silver, and 


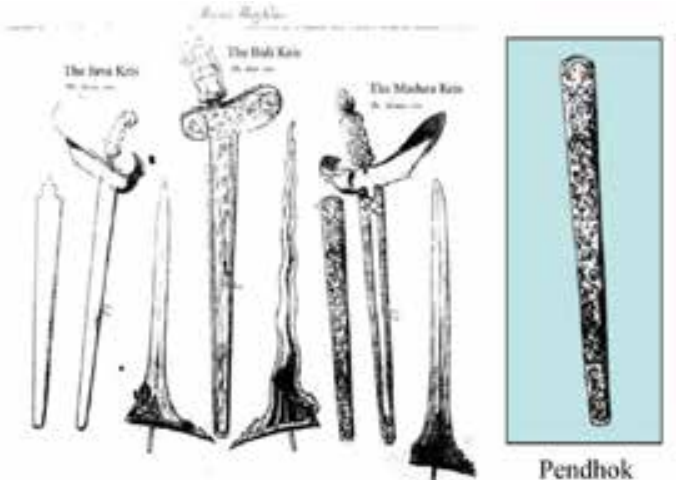

Figure 2. The types of kris and its pendhok by Raffles. Detail based on The History of Java (1817: suplement after page 296; 2008:189)

gold. The sungging's technique is on wood. The ornaments are applied on those techniques.

Javanism as the domain of ornament in Surakarta Ornaments issue from history. While Hindu tradition was retained in Bali, Java underwent an Islamization process. Yet, many Hindu aspects of tradition were preserved in the palace culture of Java. (Prijohutomo, 1953:105-106). Ornaments, be it for houses or clothings, continued being created in a context of patronage as a prerogative of the local royalty (Pigeaud, 1962:384). The kris was adopted and further developed by the pasisir rulers revered as 'apostles of Islam (wali sanga) (Lieberman, 1999: 270). With roots in Islamic Mataram, Surakarta synthesizes Javanese and Moslem traditions. Ricklefs says that the synthesis undertaken by Sultan Agung was a "mystical synthesis" between the culture of the Javanese hinterland and that of the coastal area of the same island (Ricklefs, 2013:32). Muslim rulers were more affine with the traditions of pre-Islamic Javanese Majapahit than with the Islamic traditions of the Arabian Peninsula or even of the coast of Sumatra (Vlekke, 2008:xvii-xviii).

The sheath style is gayaman, and the pendhok types is bunton

In literature, "Javanization" refers to the various Indian cultural influences that penetrated Java, which then developed its own literary (Kawi) and religious culture. The kingdom of Majapahit is considered to be a synthesis of Hindu-Javanese culture, in a specific Javanese Mahäyäna way (Banerji, 1989:589; Wiryomartono, 2016:32; Ricklefs, 2013:29; Raffles, 2008:252-264; Kern (in Pigeaud, 1962:3). Its tradition was influenced by pre-Moslem 'old Javanese' and as such contains a large number of Sanskrit loan words (Uhlenbeck, 1964:108, Zoetmulder, 1974:8; Auroux, 2000:187). Interestingly, floral motifs related to Buddhism and Hinduism such as lotus or chakra (Kossak \& Watts 2001:25) did not exist in Old Javanese and are therefore 'absent' from the ornamental tradition of Islamic Mataram, as well as of Surakarta.
Traditions such as slametan raja wedda and maesa lawung inherited from Majapahit were actually passed down through Demak (the first Islamic kingdom in Java) into Mataram-Kartasura in the era of PB II, 1748 (Headly, 2004:292-294; Headly, 1979:49-57). But not all the Surakarta ornamentation rests on the Hindu-Javanese iconography of nature. In Hindu-Buddhist tradition, ornaments features anima motifs such as birds, peacocks, elephants, and horses. Leaf motifs are also widely used, often in curly forms. Flowers are depicted in a naturalistic way, complete with stems and leaves (Wahby 2007). Hindu flora's ornaments are common. Mythological animal figures such as Ganesha and Garuda are also frequent. Those animals are symbols and vehicles of Hindu imagery (Miyazaki 1988:148).

During the Islamic period in Java, many pre-Islamic elements were incorporated in the new tradition. The form of motifs was stylized to the extreme, as seen in the art of wayang (the shadow play), and in ornamental motifs found in mosques and at the royal palace. The advent of Islam did not eradicate figurative representation, but tended to 'abstract' its essence (Wahby 2007). The art of pendhoks reveals the resilience of a Hindu 'imaginary', yet bereft of symbols and images such as lotus, chakra, and Hindu gods. The vegetation motifs in found in temples became a stylistic source for ornaments.

\section{LITERATURE REVIEW}

\section{The Mranggi in Post-Kartasura imagery}

Dring the Mataram dynastic conflict the location of the royal palace was transferred first to Kartasura, then to Surakarta. The Surakarta kris is rooted in Islamic Mataram, but its peculiar proper appeared during the reign of Sunan Pakubuwono III (1749-88), thus after the third Javanese war of succession. Then, the style of the kris and its related components such as the pendhok were normalized to better distinguish them from their Kartasura and Yogyakarta equivalents. The Surakarta kris was identified as having a smaller body compared to its Kartasura equivalent, but after the Palihan Nagari (Agreement of Giyanti), it was also said to be bigger than the Yogyakarta kris. The kris, which previously was a weapon, became an instrument of identification of aristocratic blood, as a part of Javanese tradition.

Today, the mranggi is known as kris and pendhok maker. This profession has survived through the days of Majapahit, Demak, and Mataram. In Later Mataram, village names often reflected its people's profession. Thus, in Kotagede, when the royal court was established, the village of Mranggen was derived from mranggi (Nakamura 2012:40). The villagers' skill were inherited from their "Wong kalang" ancestors---the Kalang people being originally war captives of Sultan Agung. They became part of 


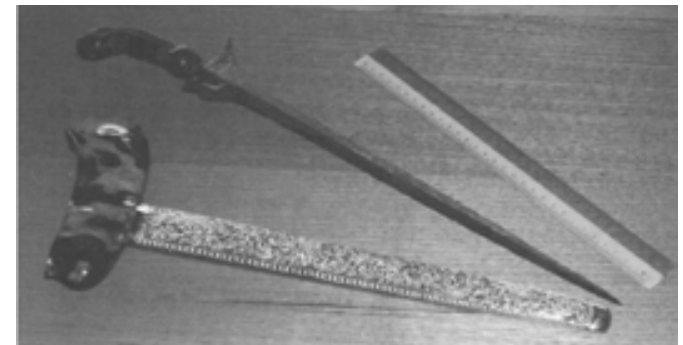

Figure 3. The Kiai Wali, 15th or 16th century made by Sunan Giri, the handle of Surakarta from $19^{\text {th }}$ century (Ricklefs, Islamize Java, 2013:31)

the palace bureaucracy and of the system of patronage, in particular that of the king (Wiryomartono, 2016:9). Yasadipura II, the famous poet of Paku Buwana IV's reign insisted that the Javanese adat (Hindu-Javanese tradition) should be maintained, and that the priyayi nobility should not invent its own adat (Riddell \& Street, 1997:270). In fact kejawen (Javanism) was identified as a form of syncretism, a particular form of Javanese-Islam, different from that practiced by the santri (Islamic scholars) (Mulder, 2005:21; Janowski \& Kerlogue, 2007: 24-33; Cederroth, 1991:18; Hooker, 1988:63).

The pándi/pande (ironsmith) or empu (kris masters) manufacture the kris blade; the manufacturer of the kris scabbard is called meránggi/tukang warongko, a word related to mergongso (carpenter) (Raffles, 1817:173, Raffles, 2008:38-39,103,110). The manufacturing of kris has been written in term of industry, with specialists such as pán$d i$ or empu (iron-smith and kris masters), meráng 'gi or túkang-weróngko (kris-sheath maker), túkang-tambógo (coppersmith), kamasán or pande mas (goldsmith) (Raffles 1817:164; Ma Huan 1970:88; Haryono 1991-1992: 62-63; Subroto \& Pinardi 1993:210). Kris making has become a traditional industry, and the pendhoks were manufactured following the characteristic of the Surakarta kris.

The mranggi is also popular with regard to jamas, the cleaning of heirlooms, which usually takes place on the first of Sura (the new year of Java), in a sacred tradition called jamasan (KRT Sumowijoyo, 2012). In this context, the kris is a waris heirloom and not a weapons. It carries traditional 'religious' significance and power. The mrang$g i$ is the person entitled to perform this tradition (Geertz, 1980:229).

\section{The aesthetics of the pendhok of the Surakarta kris}

Since the early times of palihan nagari, the political elites of Yogyakarta and Surakarta have claimed to be the legitimate descendants of the Kartasura dynasty. As military power and and politics were controlled by the Dutch East India Company (VOC), they looked for legitimacy in culture. The Babad Kraton ( Palace Chronicle) was composed to legitimize Yogyakarta as the true heir of the Kraton Kartasura (Ricklefs, 1974: 213-218), and Arjunawiwaha was written to link Pakubuwana (PB) III and Surakarta

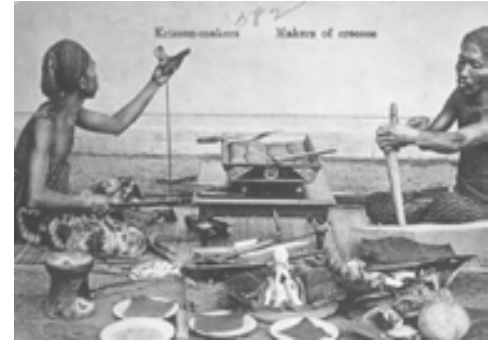

Figure 4. The Kris maker

Source: https:/www.pinterest.com/pin/690176711614235378/ (accessed 15 April 2018)

to the Kartasura tradition (Wiryamartana 1990: 402-409). During the time Vorstenlanden (Princely Lands), the political power of Mataram was indeed weakened by the Dutch. The royal courts sought to maintain their authority on society through the use of [1]: Personal symbols such as titles, clothing, honor, star of services, and lifestyle $f$ leisure and hedonism; [2] Public symbols, in the form of support of tradition, nationalism, religiosity, and intercultural behavior (Kuntowijoyo, 2004:22-41).

The foundation of the city of Surakarta dates back to the Tangguh Nom proclamation and (Mataram - Kartasura - Surakarta) and to Dutch colonialism. It was further underlined by changes in the judiciary. The Kraton Surakarta was founded by Pakubuwana II in 1745, and for almost 250 years represented authentic Javanese culture at its highest level (Florida, 1993:11). During colonization, while Westernization occurred across the board, the kris became for the Kraton a symbol of resistance (Lombard, 1990:107-112).

The dialectics of the two "Java" models exemplified in Surakarta by the Kraton and the Mangkunegaran produced "Javanese" style. Whereas the Mangkunagaran Palace had its own pleasure retreats and ritual kinks, the Kraton Surakarta remained the original post-Kartasura model (Pemberton, 1994:112). Suryono (2012) says that the king's privilege as successor to the kings of Java is to have a kris master and a special tangguh (the style). This is only found at the Kasunanan; the Mangkunegaran does not have this tangguh privilege because its title is only that of Adipati Anom (Duke). The Surakarta kris is smaller his Kartasura equivalent, but since the Palihan Nagari (Giyanti agreement), the Surakarta kris has always been bigger than his Yogyakarta equivalent. The principalities of Yogyakarta and Surakarta have had separate 'Power' and existence for more than two hundred years, even though they are less than forty miles apart (Anderson, 2006:42).

The pendhok types and forms followed the tangguh (style) The tangguh itself appeared in the post-Kartasura era, and was known as Tangguh Surakarta in 1749 during the Pakubuwana IV - X. Its successive empus were Brajaguna, Brajasetika, Ki Tirtadangsa, R.Ng Jayasukadga, R.Ng Japan, R.Ng Singawijaya, R.Ng Brajasetama, R.Ng Wira- 
sukadga, and Ki Mangunwalela. Some texts say that the PBIII kris were too straight. If the kris in PB IV era were around $37-38 \mathrm{~cm}$, then shortened to about $35 \mathrm{~cm}$, it was still longer than the Yogyakarta kris.

The pendhok have been categorized by materials, techniques, types and forms, as well as function. The material consists of metals such as: brass, silver, gold, or swåså (a mixure of metals with a gold appearance) (Groneman 1910:188). Based on the form, there are several types of pendhok: blewah/slorok, bunton, topengan, and kemalon (Groneman, 1910:188; Haryoguritno, 2005:335). Based on the manufacturing technique, pendhok are categorized into pendhok krawangan, tretes, cukitan, and tinatah. According to Harsrinuksmo and Lumintu, pendhok kris relate to ethics. There are certain pendhoks which can only be worn by noblemen, such as the pendhok kemalon, which has a white background, and the pendhok tretes with has a specific sheath and should only be worn by the king.

The pendhok is an embossed white metal plate (Stone, 1999:282,392). Groneman defines the pendhok serves as a sheath wärängkä protection (Groneman, 1910:188). Haryoguritno (2005:333) defines it as a metal covering for the kris sheath: kandelan (confidence). The simplest pendhok are usually made of brass or copper, but luxurious ones are made of silver or gold set with diamonds (Purwadi, 2005:381). If the pendhok of Yogyakarta kris uses traditional motifs such as semen tritis (Andono 1995:19), the ornaments found on the Surakarta pendhok is usually the lung-lungan. Paku Buwono XIII (2005-2011), wore a kris in the gayaman style, and its pendhok ornament was as a motif of sweet potato, underlining rhythm and believed to embody the idea of sustainable living (Hidayat, 2012:105).

\section{METHODOLOGY}

The ornaments of the pendhok in this essay were mostly made by the mranggi of the 1980s generation. The form of kris which have been used as a 'model' for those pendhok is the Surakarta kris, derived from the tangguh nom (young period, Mataram - Surakarta). The pendhok choosen is the kris alusan (refined) or ageman, and not the kodhian (unrefined). Technically, the pendhok followed the norm of the Surakarta kris, for which ornament is only decorative. According to Read (1936:121), there are three considerations in the making of ornaments: 1) Size, related to its appearance on the object. 2) Form, the way it fills space, and the possibility to repeat it in a linear rhythm, continuing it, multiplying it-up to the infinite 3) Association, related to the application of ornaments. Those principles determine the various 'signs' defining style: elements, qualities, and expression (Meyer, 1953: 287). The analysis of the style of primitive and early historical cultures has been influenced by Western recent standards (Meyer, 1953:290). But, Meyer's argument is used here to see ornaments as a survival of the past, and the motifs are categorized in the

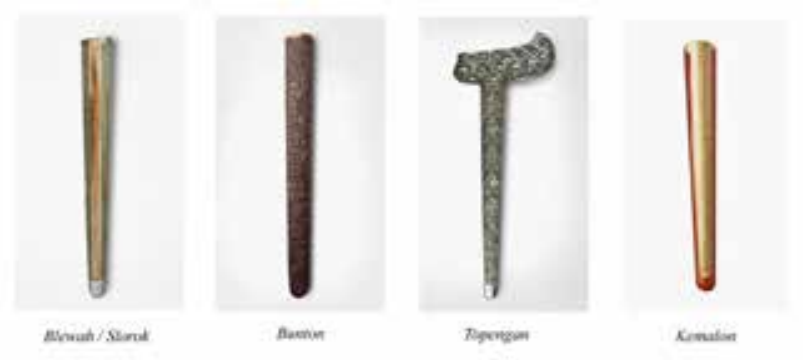

Figure 5. The types of pendhoks

form of style, and in the form of expression. The research findings are a signs that have the rights to refers as the signs of the style.

This essay uses a qualitative exploratory approach to investigate the $1980 \mathrm{~s}$ generation of pendhok craftsmen in Surakarta. The study focuses on the ornaments on pendhok, also designs, and sketches. There are two kinds of data used: written and visual materials. The written material includes information, ideas and opinions that have been published in journals and books, online publications, and also material written in the form of academic papers. The visual data includes images and photos.

The data was analyzed using a qualitative approach, and the visual exploration focused on the artistic aspects (Meyer, 287), with attention to the iconography, i.e. the link between motifs and compositions with themes and concepts (Panofsky, 1955: 28-31; Panofsky, 1939: 5-8). At this stage the motifs becomes the conventional subject matter, it is necessary to search the text of reference to seek awareness of a certain representation. Finally, this essay studies the pendhok ornaments applied to the Surakarta kris, aiming at define the pendok ornaments as a collective sign indicative of the Surakarta style.

\section{DISCUSSION}

\section{The types of pendhok}

It is known that pendhok of Surakarta have a certains style such as bunton, blewah, topengan, and tretes. The pendhok bunton is covers all parts of the gandar (axle) of warang$k a$ (sheath), and pendhok krawangan usually refers to the carving technique on material which is achieves of engraved translucent. While, pendhok blewah has a vertical hole on the frontside, the aim is to show the wood pattern. The pendhok topengan has a whole decorated ornament on every side-surface with engraved translucent, in classic style, it is said normally uses a motif of topeng (mask) or head of Kala (giant), and masking all sheath. The pendhok tretes is mostly uses a precious stones, at beginning, it was used by nobility only (Harsrinuksmo and Lumintu 1988:130; Wibawa 2008:45).

Although the discussion of an ornaments on pendhok is limited, but, according to Groneman, the ornaments is just as motifs in batik. There are some pendhoks with a spe- 
cial motif such as semen jlengut may only use by kings (Groneman, 1910:189), and the sunggingan sheath with a motif of alas-alasan (jungle) with a white background only be worn by the king (Harsrinuksmo \& Lumintu, 1988:189). While the nobilities such as regents, tumenggung, and riya wore a pendhok with unthuk-unthuk motif (Groneman, 1910:189).

The ornament in Surakarta is existed in many objects, both functional and cultural. The classic's motifs were applied in batik such as sawat, meru, naga, geni, (Siwomihardjo, 2011:15), semen, and parang. The 'Classic' in batik is referring to the Kraton (Dharsono, 2007:50). The pendhok is using a carving technique with a patterned pieces of plants or animal, the images of plants carved in the form of flowers, and animals, consist of a bird or a deer (Haryoguritno, 2005:333). There are some 'patronage' patterns in varieties of lung-lungan, the embellished shape in stylistic forms, until does not recognize the original vegetation (Haryoguritno, 2005:337). The motifs are: alas-alasan (jungle), garuda (the steed of Vishnu), lung-lungan (vegetations), pari sawuli (rice plants-inspired from kris nickle), wilaya sarimbit (couple), modang (the power to muffle wrath), menyan kobar (flaming of olibanum), gringsing (repellent reinforcements), anam gedeg (a woven bamboo motif symbolizes togetherness), parang (patterned like a sword showing power), and others (Harsrinuksmo, 2004:362).

The motifs which found in pendhok bunton are variations of lung (vegetation), such as: kembang setaman (harmony of flower garden), sari kretarta, widasari, and kraton (palace). In pendhok blewah, the motifs are variations of lung: anggur (grape), kertas (bougenville), combrang (etlingera elatior), wajik (diamond), budha, kenanga ginubah (reshaped cananga), modang, and plisiran (Yunus 2012). The four motifs or its similarities which commonly known in pendhok are: lung/lung-lungan (vegetations plants), alas-alasan (forest and its animals), geometrycal shape (wajik, nganam kepang, anam gedeg), garuda or another mythological animals.

The Surakarta kris has been derived from a spesific discourse the kris of Tangguh Nom (Mataram - Kartasura - Surakarta) and Dutch colonialism, and promoted by changes in court policy. The style of ornament is related with the Surakarta kris as the main object. To identify the style of ornaments on pendhok, the craftmans are reffering the kris of tangguh nom (young period) as the model of pendhok. The kris have lenght about $35 \mathrm{~cm}$, the top-wide is around 4,2 cm and the bottom-wide is $2,5 \mathrm{~cm}$, and the tickness of materials around $0,6 \mathrm{~mm}$, with the top of tip is horizontal.

\section{The style of ornament on pendhok}

It is known two types of ornaments: naturalistic, and stylized. The naturalistic is a form of ornament which has taken the natural phenomena as the source...meanwhile

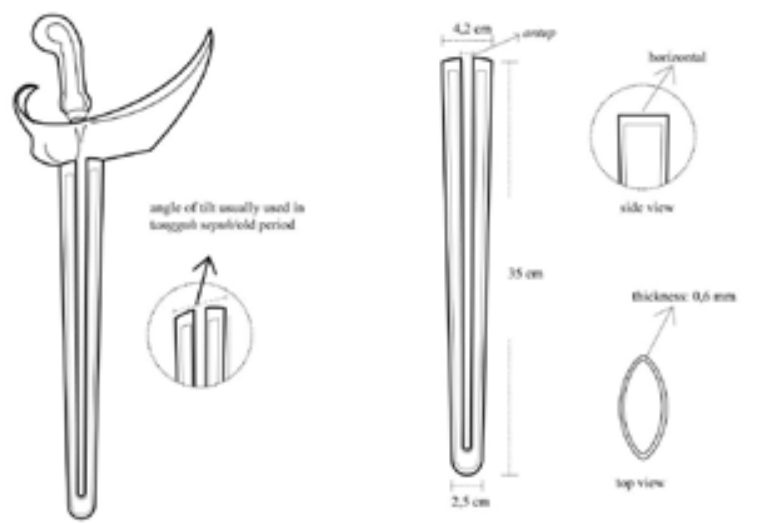

Figure 6. The anatomy of pendhok blewah in Surakarta style Illustration by Dhoni Kustanto

the stylized ornament has a form based on stlizing the basic form, it has a free style to change the previous form (Guntur, 2004:38-40). The naturalistic ornament has an iconographic form such as sulur-suluran (the ryhtmic vegetation). The motif of plants has been formed into a kind of sulur-suluran of wood carving in Classic period of kingdoms in Indonesia (Syafii and Tjetjep, 1987:18). It is said that the classic wood carving in the Court was oriented to the Kings, and the craftmen or the authors are unrecognized, in the end, only known by the places where the motifs are growing up, such as Surakarta and Yogyakarta (Syafii and Tjetjep, 1987:7). In ornament of wood carving, the Surakarta motifs have been said taken from the stylized of patra (leaf) of pakis (fern) vines, and later called a lung-lungan.

The ideas of ornaments are came from: alas (forest), plants, animals, animal mythology, puppetry, geometry, decorating fields, and the beauty of artificial objects. In general, the motifs that mostly used on pendhok are lung-lungan and alas-alasan, and the ornamentation which is used eventually is pahatan (engraved). The ornaments have a size gradation from bottom to the top, it is a scaling an appearance of motifs. The motifs which are applied into a form of ornaments, have been designed to have a possibilities to repeat the motifs in a vertical-linear rhythm, continuing it, multiplying it up to the optimum.

The ornaments have a qualities of form, and the materialization of motifs is concepted as an expression. In general, the study of style tends toward a correlation of form and expression. Indeed, ornament has been characterized, or termed like "stylized", "archaistic", and "naturalistic". Some motifs that often found on pendhok are described as follow.

The lung-lungan as the main pattern of ornament The Lung-lungan is an ornament based on vegetations, and formed in a curly stylized rhythm. The ornament is then 'embossed' into the form of relief, and has an expres- 

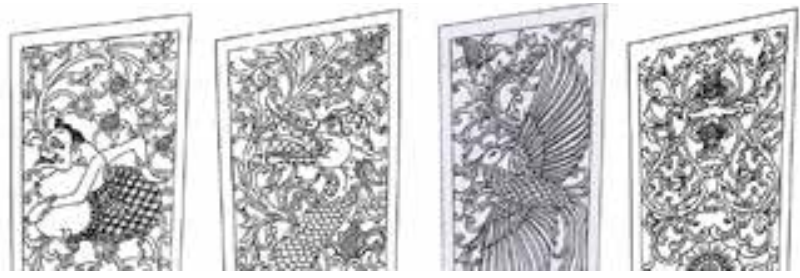

Figure 7. The pictures of traditional ornament
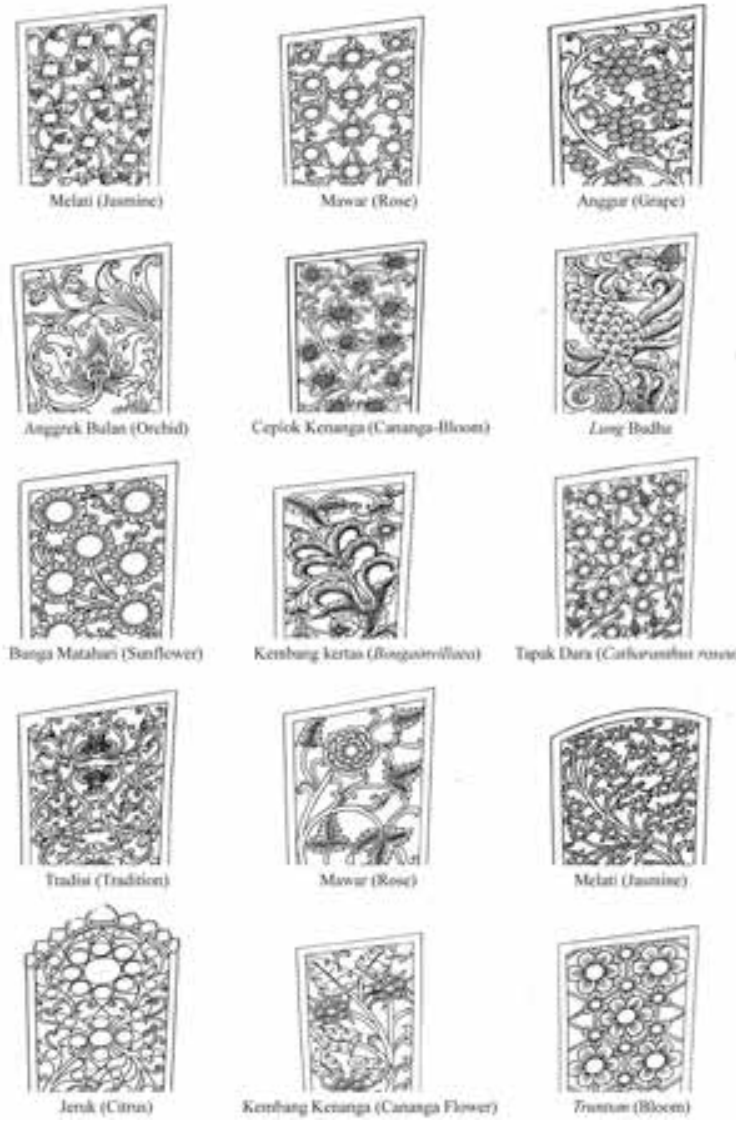

Figure 9. The motifs of plants in pendhok bunton

sion of impresse's traces of traditionality. Many motifs are inspired by the form of natural objects, such as vegetations, plants, and trees. The plants motif is manifested in the form of tendrils or lung-lungan. Various motives sourced from plants are lung: kembang sirsat (soursop), pakis (fern), ceplok kenanga (cananga-bloom), kembang kenongo (cananga), ceplok permata (diamond-bloom), simbar/paku tanduk rusa (platycerium bifurcatum), tapak doro (chantarantus roseus), truntum (bloom), kembang kertas (bougenville), anggur (grape), kembang melati ceplok melati (jasmine -bloom), mawar - ceplok mawar, anggrek - anggrek bulan, bunga matahari, dan kembang sirsat. In the nomenclature of the Javanese language, there is a division of names: kembang (flowers), lung (vines), wit (trees), and suket (grass plants). In ornamental forms, the three plant classifications: grass, flower, and trees are then deformed and "categorized" into lung or lung-lungan. The pakis is mostly grows in Pasisir utara (northern sheashore) such as Kudus and Pati.

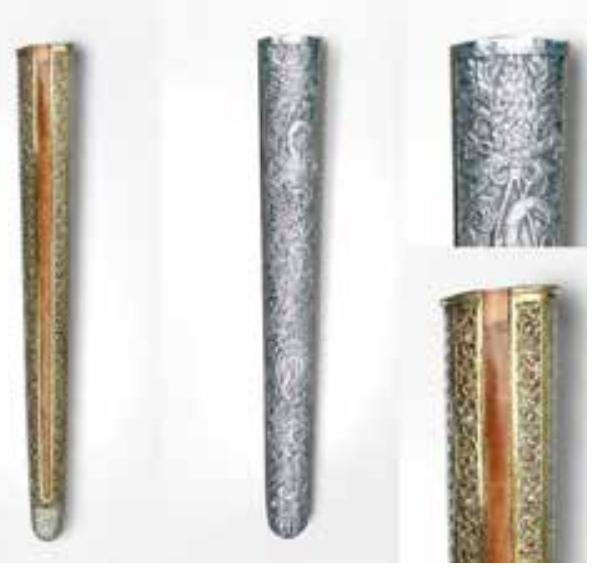

Figure 8. Left: pendhok blewah (combined with a jewels) Right: Pendok Bunton with a motif of lung pakis

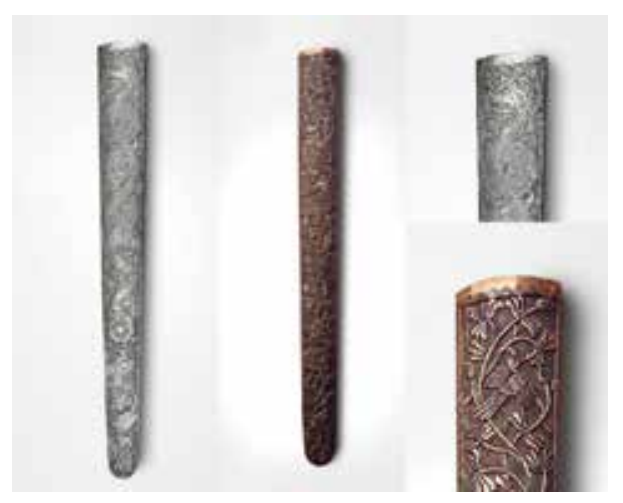

Figure 10. Naga temanten / Peksi dewata

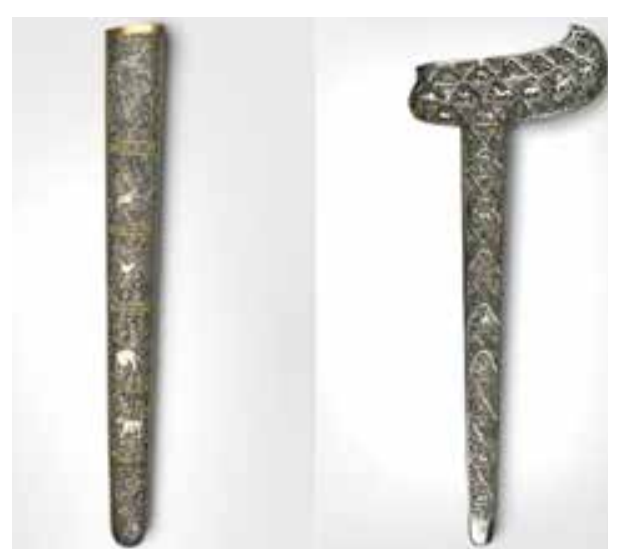

Figure 11. Alas-alasan in pendhok bunton

An alas-alasan motif based on animals and mythological animals

This motif took an inspiration from the natural animal and mythological animal as the main source of ornament. The common distinction between animal motif and alas (jungle) motif is the presence of animal variations. On the alas-alasan motif, there are various animals which composed in the hierarchy of ecosystem layers. The pictures of natural animals are found in several motifs: bird, peacock, the bird and lung, butterflies, fish and birds. 


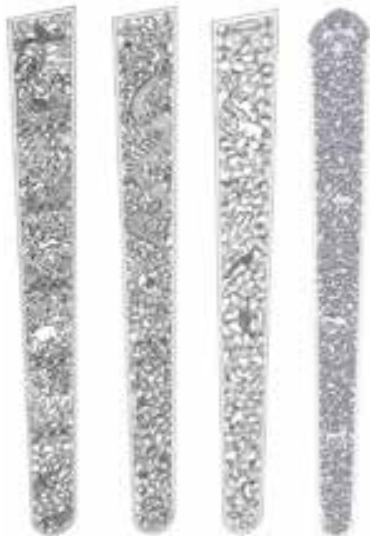

Figure 12. Design of alas-alasan in pendhok bunton

The motifs of mythological animals are: naga temanten (the bride of dragon), peksi dewata (the deva's bird), ganesha, dragon and phoenix, dragon, dragon king, hong bird, crown and dragon, twin dragons. Peksi Dewata motif also be found in the sacred place of Songsong Agem Dalem which is a sacred place of Surakarta (Marleen ed. 2004, 51). The myth, according to Montagu (1961:148) is a traditional story, accepted historically, that shapes one's beliefs about creation, god, universe, life, and death.

The ornament based on alas generally presents a number of animals with nature as their habitat. The peculiarities of alas-alasan are animals pictorial which arranged displayed on the ecosystem from the bottom to up, namely: water, land, and air. The subject matter is depicted on forest life in which there are various examples of natural animals: fish, crocodiles, tiger, deer, elephant, rhinoceros, bulls, birds, and mythical animals such as dragon, jatayu, winged dog, and lion. The bird of Jatayu or garuda is a mythological animal that can be found in the source of the puppet story. If we look at the alas-alasan in Javanese political economy, the forest becomes the embryo of the Javanese court, this becomes the basis an aesthetic inspiration and its expression can be found in various artifacts with various media variations. Forest has become an important reality in the life of Javanese society. Forest not only provides the physical potential of natural resources, but also the spiritual power of life. Forest as a whole becomes an important part of the religious, spiritual and ritual beliefs of the community (Guntur 2015:38).

A motif based on the traditions, wayang (the shadow play) tradition

The classic form of traditional ornament can be found clearly on the themes of tradition derived from: wayang; animals of mythology: dragon king's motif, ganesha, peksi dewata, dragon, phoenix, twin dragons; animals and its nature.

"Wayang tells the various acts of the gods and the Hindu heroes which are considered to take place in Djawa (Java)

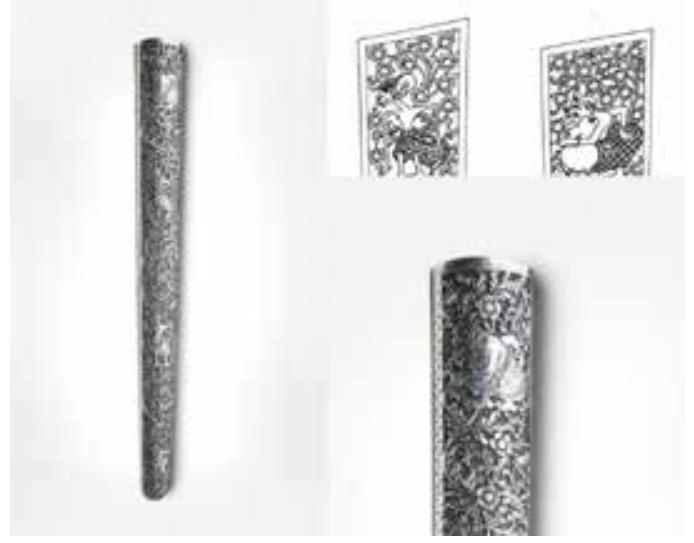

Figure 13. Punakawan dan Pandawa Lima

... The Kraton of Java is essentially the treasury of the ancient Hindu periods, called the Javanese" Buddha Period"(Prijohutomo 1953). The puppet based motif refers to the wayang emPurwadi, both in human (figure) puppets, animals, and or, scene situations. The puppet story becomes a kind of mirror of human life. Ornaments based on humans are usually more pointing to the puppet man with the visualization of the form following the puppet tradition, as manifested in the motifs of punakawan and Pandawa Lima (five pandavas). There are several other motives: goddess, peksi dewata, motifs of giants, motif of jatayu. Motifs derived from this puppet generally use tradition lung motifs. In the epic of wayang, Pandawa (Pandavas) is a binary opposition to Kurawa.

The term five Pandavas refers to five brothers, namely: Yudistira, Bima, Arjuna, Nakula and Sahadewa. In the Encyclopedia Wayang Purwa, Pandawa's story in defending its truthfulness, always tackles everything beyond humanity, cruelty and greed and evil -and Pandavas become the winner in his feud with Kurawa (Sudibyoprono 1991:375377). While Punakawan is character popularized in/by the shadow puppets, they play the role of entertainer and advisor, sometimes acting as a helper for the Pandavas who are in the trouble. The puppet function becomes a learning medium of traditional art about the characters in the community that puts the Javanese personality as a communication of wisdom.

A motif based on geometry and objects

The decorating of the space is done by incorporating motifs: 1) processing the geometric elements (dots, lines, and curves) into form on surface, and arranging them in the composition. 2) 'copy' and 'paste' the motif of the articial objects, then applied to the pendhok. The first motif is a geometrical plane composed of a combination of dots, lines, and curves without any defined pictorial significance. The result is a parallelogram, which is left empty without isen-isen (sweetener pictorial) so that it is plain as a field of geometry. The form is re-duplicated into a series that extends to the area of the decorated field (Read 


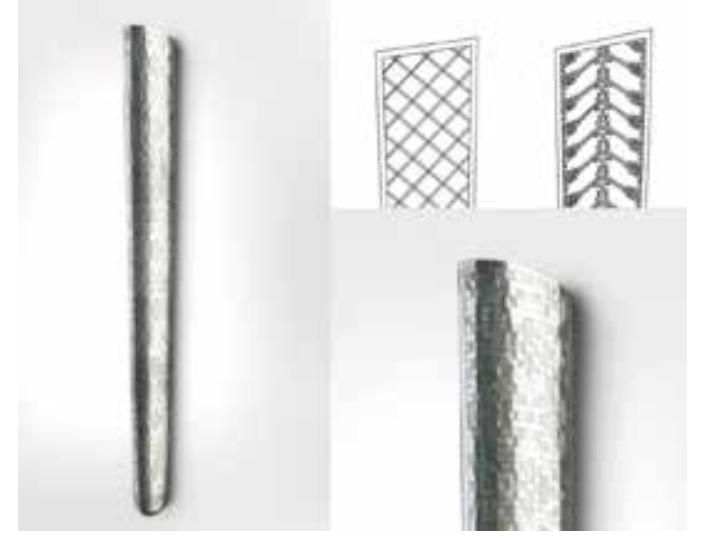

Figure 14. Nganam kepang motif

1935:119).

In addition, there is also a composition of ornaments that pluck only one motif (geometry) and arranged duplicatively, such as the motif of woven wajik, and modang motif. The second motif is sourced from composition of geometrical surface of artificial objects. The pattern of decoration is re-placed into pendhok. The method of replacing the beauty of the surface obtained by imitation of the beauty of artificial objects, such as wicker of object, with the result is nganam kepang motif.

The characteristic of an ornament is done by the way of inclusion of traditional ornament elements such as leaf, flower or fruit, ukel (spiral), and transformed the vegetations into the main pattern of lung-lungan alone or in combinations with animals. The pattern of lung-lungan often found as a background of alas-alasan motifs, animals kingdom, and wayang. Those motifs are become a specific, have a traditionality of expression compared to others. The ornamentation of motif on pendhok are using technique of pahatan (engrave) for pendhok of alusan (refines), and cukitan or wudulan for pendhok of kodhian form. The pahatan resulted more dimensional on the surface in pendhok bunton compared to the others type, and have an expression to the art of relief in temples.

\section{CONCLUSIONS}

The legitimation of Palace in making of an identity through kris, from the Kartasura to Surakarta, has shown that the 'form' has been accepted by the empu, pandi, mranggi, and folks, then became a tradition of the palace and outside of palace. That is the way of acknowledging the style of Surakarta kris by recognized its forms of sheath and handle, especially the sheath of ladrang and gayaman, with the handle of tunggak semi. During the colonization, kris is become a resistance in Kraton fashion customary, and $\mathrm{Kra}$ ton Surakarta remained the original post-Kartasura trace of cultural authenticity. The pendhok in Surakarta style was applied to the kris of tangguh nom (young period). Kris tangguh nom is identified in the period of Mataram Islam
(Yogyakarta and Surakarta) in Java until the independence of Indonesia. The ornaments are existed in many objects, both functional and cultural. The characteristics and forms of pendhok in Surakarta style were tall, and slender. The most techniques in ornamentation of pendhok's were used in period of $1970 \mathrm{~s}$ is cukitan (engravings) and wudulan (hitting the plate until it becomes a shape). The usual staining technique is practiced is a chromium of gold, silver, copper and silih asih (two colors with unified become in compositions of alternating).

The aesthetic of pendhok is different compared to the blades, the basis of pendhok beauties is ornaments, techniques, and materials. The pattern of lung is implementing into anothers motifs, the composition of the elements, form, and motifs are organizing in repetition, scaling, and gradation (Guntur, 2004:124-130 and Meyer 1957:vii). The pattern of lung-lungan is became the general basis in ornaments, either as main or additional elements. The rhythm of lung-lungan becomes the "center" in organizing various combinational elements, it is a movement from the left and to the right or vice versa that leads the motifs to the top, following the logic of growing plant, in vertical space of pendhok. The shape of lung-lungan refers to the ornamental decorations arranged continuously create the rhythm of alternating (Gustami 2007:120). The lung-lungan pattern is used primarily as the main visual subject, sometimes has placed as background that support the motion rhythm of the main elements in ornaments. Leaves are widely used, and in many cases, the style tends to turn into curls. The imagery of Hindu-Buddhism in displaying of animals, natural and mythical, is still implemented on ornament.

In process of ornamentation, mranggi normally starts from the bottom (base) to the top (tip) of pendhok. The size of the ornament usually begins with a small size and gradually getting bigger till reach to the top of pendhok. To cover the widened field of space, it has done by multiplying of elements. The tools which used frequently are pencil, paper, pen of various sizes. There is an artistic principle used in making ornaments. Some principles of an arrangement of elements is the dynamic repetition, and the process of dimensionality of the embossed surface.

The principle of dynamic repetition is to create a repetition of motif, it is used more than once in design, the form is standing in a situation of repeating its self, or looping, it is the simplest design (Wong 1972:11). A repetition has regularity, which is sought by looping is the rhythm. The lung-lungan is a loop to the left to the right or vice versa with the upward direction, so there is the impression of the rhythm. The loop occurs in the element's shape, size, direction, and position by using the opposite technique (mirroring), scaling the size, and adding elements. The iconography of lung-lungan on pendhok is symbolizing the rythm of growth and development of life in spiritual nature. 
The second principle in ornamentation is to achieve a motif into dimensionality of relief. The cukitan technique commonly used as a technique of an embodiment of ornaments on pendhok, the result ornament is flat, mostly found in pendhok of keris kodhian. The technique is works in the way of reducing the material by carving up the surface, pointing the instrument movement that is pressed to the metal and then moved upwards in an effort to take the surface of the material, so the surface is reduced.

The level of cukitan's technique is going deepened in the pahatan technique, and lead to the process the relief's techniques on pendhok. To reach the depth of relief, the craftman is using a hammer, chisel, or chisel - relief. The purpose of this technique is to make the shape of ornaments more impressed or protrude by the process of the dimensionality of the embossed surface. The relief technique has been invented to reach the distinction with another pendhok craftman, within the imagery of Hindu-Buddhist relief. The ornament is using combination imagery from epics, tradition, and cultural with. Relief is an art which applied in temples of Hindu and Budha. The ornament in form of stylized relief in pendhok is expressing the senses to the taste of ancient.

The tangguh of Surakarta kris and its formation had leading to the types or form of pendhok, and its ornament, which at first is the 'patronage' art of Palace, that accepted by mranggi. The tradition of imagery which passed down to Surakarta is mostly of Javanese traditional arts, it is the iconography of natural life. The natural which described here is symbolized in motif of lung-lungan (curly vegetation rhytm), alas-alasan (animal or animal mythology and its cosmos), and mythical naration in puppetry, others is geometry, and artificial objects. The characteristic of an ornament is done by the way of inclusion of traditional ornament elements such as leaf, flower or fruit, ukel (spiral). The style of pendhok is then visually 'embossed' alike into the form of relief.

The ornament based on alas generally presents a number of animals with nature as their habitat. The peculiarity of alas-alasan is the arrangement of animals was displayed on the ecosystem from the bottom to up, namely: water, land, and air. If we look at the alas-alasan in Javanese political economy, the forest becomes the embryo of the Javanese court, this becomes the basis an aesthetic inspiration and its expression can be found in various artifacts with various media variations. The jungle has become an important reality in the life of Javanese society, not only provides the physical potential of natural resources, but also the spiritual power of life. Forest as a whole becomes an important part of the religious, spiritual and ritual beliefs of the community (Guntur 2015:38).

A cultural ornament in the kris of Surakarta does not appear suddenly, but through the history, which could be refers back to the Hindu-Budha-Javanism's iconography of nature. The form of vegetations which transformed into embellish where found on many temples become a cultural source of motifs of lung-lungan. Seeing the way of stylization, Hinduistic flora seems to be a common form of ornaments. The ornament on pendhok in practical $\square$ ritual, it has a cultural meaning. During the Islamic period in Java, a traditional art shown the adoption of the pre-Islamic. The forms, sometimes after further process and extreme stilization, the advent of Islam does not really eradicate figural representation in ornaments of pendhok. Today, pendhok is signifying the ornament as beautify, or harmonicity in form of dressing. But, more important, the ornament on pendhok is represents the important part of the spiritual and ritual beliefs of the imagined community of "Java".

\section{REFERENCES}

Anderson, Benedict R. O'G. (2016), Language and Power: Exploring Political Cultures in Indonesia. First Equinox Edition.

Andono. (1995), Study of Ornament on Pendhok's of Keris. Research report at Lembaga Penelitian Institut Seni Indonesia. Yogyakarta: Indonesian Institute of Arts.

Banerji, Sures Chandra. (1989), A Companion to Sanskrit Literature: Spanning a Period of Over Three Thousand. Delhi: Motilal Banarsidass Publ.

Brown, Rebecca M. and Hutton, Deborah S. (ed.). (2011), A companion to Asian Art and Architecture. West Sussex: Blackwell Publishing Ltd. United Kingdom.

Dharsono (Sony Kartika) and Sunarmi. (2007), The Aesthetic of Archipelago's Visual Art. Surakarta: ISI Press.

Florida, K. Nancy. (1993), Javanese Literature in Surakarta Manuscripts: Introduction and manuscripts. Vol.1, Introduction and Manuscripts of the Karaton Surakarta. SEAP, Southeast Asia Program. New York: Ithaca, Cornell University.

Geertz, Clifford. (1980), Negara: The Theatre State in Nineteenth-Centry Bali. New Jersey: Pricenton University Press.

Guntur. (2015), “Alas and Gunung: Their Representation in the Javanese Traditional Batik". In Arts and Design Studies, www.iiste.org, ISSN 2224-6061 (Paper) ISSN, 2225-059X (Online), Vol.27.

Groneman, Isaäc. (1910), Der Kris Der Javaner. vol. 19, pp. 91-109; 123-161; 179-211 + Tafel XXV-XXXIV. 
Gustami, SP. (2007), The Grains of East Aesthetic, Basic Ideas of Creation of Indonesian Craft Art. Yogyakarta: Prasistwa.

Haryono, Timbul. (1991-1992), "Gold Metal: Function and Meaning in the Ancient Javanese Society Cultural System in 8-15th Century". Yogyakarta: A Research Report, The Faculty of Literature, Gadjah Mada University.

Harsrinuksmo, B. and Lumintu,S. (1988), Encyclopedia of National Culture: Kris and Other Traditional Weapons. Jakarta: Cipta Adi Pustaka.

Harsrinuksmo, Bambang. (2004), Kris Encyclopedia. Jakarta: Gramedia Pustaka Utama Publisher.

Haryoguritno, Haryono. (2005), Javanese Kris between Mystics and Reason. Jakarta: PT. Indonesia Kebanggaanku.

Hidayat, Taufiqurrahman. (2012), The Costume of Paku Buwono XIII on Rites of Throne (Tingalan Jumenengan Dalem) 2005-2011. Undergraduate theses. The Faculty of Literary and Visual Art. Surakarta: University of Sebelas Maret.

Hooker, M.B. (1988), Islam in South-East Asia. Leiden: E.J. Brill.

Headly, Stephen C. (2004), Durga's Mosque, Cosmology, Conversion and Community in Central Javanese Islam. Singapore: ISEAS (Institute of Southeast Asian Studies).

Headly, Stephen C. (1979), “The Ritual Lancing of Durga's Buffalo in Surakarta and the Offering of its Blood in the Krendowahono Forest”. In Francien van Anrooij, Dirk H.A. Kolff, Jan T.M. van Laanen, Gerard J. Telkamp. Between People and Statistics Essay on Modern Indonesian History. Amsterdam: Martinus Nijoff, the Hague, under the auspices of the Royal Tropical Institute.

Janowski, Monica \& Kerlogue, Fiona (ed.). (2007), Kinship and Food in South East Asia. Denmark: NIAS (Nordic Institute of Asian Studies).

Kossak, Steven M. and Watts, Edith W. (2001), The Art of South and Southeast Asia, A Resource for Educators. New York: The Metropolitan Museum of Art.

Kuntowijoyo. (2004), Raja, Priyayi dan Kawula. Yogyakarta: Ombak.

Lieberman, Victor. (ed.). (1999), Beyond Binary Histories. Re-imagining Eurasia to C. 1830. The University of Michigan Press.
Lombard, Denys. (1990), Nusa Java: Cross Cultural. Vol I: Boundariess of Westernization. Jakarta: Gramedia Pustaka Utama.

(2000), Nusa Java: Cross Cultural. Vol. 3: The Heritage of the Concentric Empires. Jakarta: Gramedia Pustaka Utama.

Marleen, Heins (ed.). (2004), Surakarta Palace. Jakarta: Foundation of the Culture of the Surakarta Palace.

Margana, S. (2005), Surakarta Kingdom and Yogyakarta 1788-1880. Yogyakarta: Pustaka Pelajar.

Meyer, Schapiro. (1953), Style. In Anthropology Today, An Encyclopedic Inventory. Chicago: The University of Chicago Press.

Meyer, Frans Sales. (2007), A Handbook of Ornament. New York: The Architectural Book.

Miyazaki, Koji. (1988), The King and The People: The Conseptual Structure of A Javanese Kingdom. Proefschrift. Leiden: Rijksuniversiteit te Leiden.

Mulder, Niels. (2005), Mysticism in Java. Yogyakarta: Kanisius Publishing House.

National Geographic Indonesia. (2012), Di Balik Tradisi Memandikan Pusaka di Bulan Sura. KRT Sumowijoyo. 23 November 2012. http://nationalgeographic.co.id/berita/2012/11/di-balik-tradisi-memandikan-pusaka-di-bulan-sura (accessed 14 April 2018)

Nakamura, Mitsuo. (2012), The Crescent Arises over the Banyan Tree. A Study of the Muhammadiyah Movement in a Central javanese Town, c.1910-2010. Singapore: ISEAS (Instute of Southeast Asian Studies).

Panofsky, Erwin. (1955), Meaning in The Visual Arts. Doubleday Anchor Books.

(1939), Studies in Iconology. New York:

Oxford University Press.

Pemberton, John. (1994), On the Subject of “Java". Ithaca and London: Cornell University Press.

Purwadi. (2005), Encyclopedia of Javanese Culture. Yogyakarta: Bina Media.

Prijohutomo. (1953), History of Indonesian Culture I, Hindu Nation. J.B. Wolters- Djakarta, Groningen.

Riddell, Peter G. and Street, Tony. (1997), Islam: Essays in Scripture, Thought and Society. A Festschrift in Honour of Anthony H. Johns. Leiden, New York, Koln: Brill. 
Raffles, Thomas Stamford. (1817), The History of Java. Vol.1. London: John Murray, Albemarle-Street. (2008), The History of Java. Yogyakarta:

Narasi.

Read, Herbert. (1935), Art and Industry, The Principles of Industrial Design, New York. Harcourt, Brace and Company.

Ricklefs, M. C. (2008), A History of Modern Indonesia since c. 1200. New York: Palgrave MacMillan.

Ricklefs, M. C. (2014), "Babad Giyanti: Source History and Literary Masterpieces of Java". Jumantara, Vol 5 No. 2, October.

(2002), Yogyakarta Under Sultan Mangkubumi 1749-1792: The History of Javanese Division. Yogyakarta: Matabangsa.

(2006), Mystic synthesis in Java: a history of Islamization from the fourteenth to the early nineteenth centuries. Norwalk: EastBridge.

(2013), Islamisation and Its Opponents in Java. Jakarta: PT. Serambi Ilmu Semesta.

Subroto, Ph., \& Pinardi, Slamet. (1993), Industrial Sectors in the Majapahit Period in 700 Years of Majapahit: an Anthology. Surabaya: Regional Tourism Official Agency of the Province of East Java.

Sudibyoprono, Rio. R. (1991), Encyclopedia of Purwa Puppet. Jakarta: Balai Pustaka

Suryono Joko, Soelistyo. (2012), The Existence of Surakarta Kris. Papers presented in Initiating the Museum of Kris Surakarta. The Hall of Tawang Arum, Town Hall of Surakarta. 1 September 2012.

Uhlenbeck, E.M. (1964), A Critical Survey of Studies on the Languages of Java and Madura. The Netherlands Institute for International Cultural Relations. The Hague, Netherland: Martinus Nijhoff.

Vlekke, Bernard H. M. (2008), Nusantara: a History of Indonesia. Indonesian Trans.: Samsudin Berlian. Jakarta: KPG (Kepustakaan Populer Gramedia).

Wahby, Ahmed E. I. (2007), The Architecture of the Early Mosques and Shrines of Java: Influences of the Arab Merchants in the 15th and 16th Centuries, Volume 1: The Text. Dissertation in der Fakultät Geistes und Kulturwissenschaften (GuK) der Otto-Friedrich-Universität Bamberg, Bamberg.
Wibawa, Prasida. (2008), The Enchantment of Tosan Aji. Jakarta: Gramedia Pustaka Utama.

Wiryomartono, A. Bagoes P. (2016), Javanese Culture and the Meanings of Locality: Studies on the Arts, Urbanism, Polity, and Society. London: Lexington Books.

Wong, Wucius. (1972), Some Principles of Designing Dwimatra. Bandung: Penerbit ITB

Yuwono, Teguh Basuki. (2012), Indonesian Kris. Jakarta: Citra Sains LPKBN.

Yunus, Toni. (2012), Kris: An Interpretation. Panji Nusantara Community.

Zoetmulder, Petrus Josephus. (1974), Kalangwan. A Survey of Old Javanese Literature. The Hague: Martinus Nijhoff. 